\title{
Introduction: what's wrong with Keynesian economic theory?
}

\section{Steven Kates}

\section{INTRODUCTION}

I was in the process of writing an introduction to a book which I like to call my Anti-Keynesian Reader, but whose official title is Keynesian Economic Theory and its Critics. It is a compendium of all of the major critics of Keynesian economics written since the publication of The General Theory in 1936. In writing the introduction to this other volume, it became obvious that no one had ever written an all-encompassing critique of Keynesian economic theory from a classical pre-Keynesian perspective. This was because when the General Theory was published, although there were many classical economists, no one at the time truly understood what the General Theory was about. Now that we do understand what the General Theory is about, there are no classical economists left to explain from a pre-Keynesian perspective what is wrong with Keynesian macro.

What else I learned was how few economists there are today who are actively anti-Keynesian. The entire literature since 1936 devoted to explaining what is wrong with Keynesian theory would hardly cover a single library shelf, and this would include both books and articles. Those of us writing critiques of Keynesian economics today are part of a very small cohort of economists.

And while I have my own form of understanding of why Keynesian economic theory is fallacious, I well understand that others also recognize the damage Keynesian policies cause, but base their criticisms on different kinds of reasoning. Yet, in spite of these differences, all of the contributors to this volume agree that Keynesian economic theory is fallacious to its very roots and cannot be used as a sound basis for public policy. Each of us has our own particular reason for our beliefs. And, in saying this, Keynesian economic theory, for the purposes of this collection, is defined as the mainstream macroeconomics that forms the core of virtually every introductory economics text and which had been the basis for the stimulus that followed the Global Financial Crisis (GFC) in 2008-09. 
The essential element of Keynesian theory is recognizable by its signature equation: $\mathrm{Y}=\mathrm{C}+\mathrm{I}+\mathrm{G}+\mathrm{NX}$. The equation states that aggregate output is the sum of the various components of aggregate demand: consumption, investment, government spending and net exports. It is then assumed that output can be increased through an increase in aggregate demand that occurs through an increase in any of the components, with the particular emphasis on the level of government spending. The further assumption is that the higher the level of aggregate demand, the higher the level of employment. This has been the basis for economic policy since the 1940s. And while there has never been a policy success that has followed the introduction of a Keynesian stimulus, the undeniable fact is that Keynesian theory has remained embedded in our texts, impervious to all of its failures. The aim of this book is to assist others in understanding the flaws in Keynesian economics and the urgent need for alternative approaches to policy.

In putting this collection together I approached only those who had previously written critically on Keynesian economics. What follows is a composite of all of the various letters sent out, which were each tailored to the specific person I was writing to.

Edward Elgar has agreed to publish a collection of articles on what is wrong with Keynesian economics. I am therefore writing to ask you to contribute to this collection.

In preparing for my own role in this, I went back and re-read Henry Hazlitt's incomparable The Failure of the New Economics, which has not aged a day since it was published in 1959 . What is also true is that hardly any economist today could understand what he was getting at, since economic theory no longer even teaches what needs to be understood to make sense of what any economist would have found second nature in 1935. But at the end, on page 437, there was this, which is even more true now than it was then.

There must be hundreds of economic books that may be variously described as Keynesian, pro-Keynesian, semi-Keynesian, or "post-Keynesian," and there must be thousands of such pamphlets and articles; but there is a great dearth when we come to any literature since 1936 that may be described as definitely anti-Keynesian - in the sense that it is explicitly and consistently critical of the major Keynesian doctrines. In the works of such writers as Ludwig von Mises, F.A. Hayek, Wilhelm Röpke, Frank H. Knight, Jacques Rueff, and others, we do indeed have an impressive non-Keynesian literature, based on "neoclassical" premises, with occasional explicit criticism of Keynesian tenets. But full-length books exclusively devoted to a critical analysis of Keynesianism may be counted on the fingers of one hand. (Hazlitt 1959: 437)

There is then an equally startling passage from William Hutt's Keynesianism Retrospect and Prospect, which is a quite sobering statement given the state of theory today. This was published in 1963:

The Keynesian fallacies remain deeply rooted, and the lag is likely to be long before they are eradicated. In spite of the retreat, there have so far 
been practically no changes in the textbooks or in undergraduate teaching. Students of this generation are still, on the whole, being trained in defective methods. A minority of them manage ultimately to think their way through. The majority are unable to. The confused thinking on which Keynes's case was framed remains the conventional foundation of the modern teaching of economics. (Hutt 1963: 431)

I have just finished for Elgar an 1800-page two-volume set on the critics of Keynesian economics which covers just about everything written since 1936 that is critical of Keynesian theory. The book would have been published sooner but was delayed because I was certain, given the comprehensive failures of the stimulus after the Global Financial Crisis, that there had to be a large cache of articles that for some reason I had not yet stumbled upon. My conclusion now is that there are no such articles anywhere. I am not even sure there are a hundred economists in the world who would explicitly describe themselves as "anti-Keynesian" in any kind of active sense.

Here is the thing: there are, for all practical purposes, no anti-Keynesians left. We are trying to hold the fort for a better time. But if after all of the problems and the non-recovery in the US there are not now legions of economists who are seeking answers to what went wrong, I don't know what can be done to change economic opinion over the immediate future. What I am aiming to do is to set down a battle standard so that others will at least know that there are serious economists who completely disagree with Keynesian macro and that there are other ways of understanding how an economy works. What I am saying is that I need you to contribute to this book because it requires people of your standing to ensure that it will get read. Nor has the catastrophe that has followed the introduction of the stimulus been unforeseeable by those who understand matters differently from those who follow the modern Keynesian consensus. At the very start of the stimulus at the end of 2008 I wrote an article published the following March, titled "The Dangerous Return to Keynesian Economics". My five-yearslater follow-up, which basically noted that everything I had said then had come to pass, had the title: "Keynesian Economics' Dangerous Return - Five Years On". [The two articles are brought together as my own contribution to this volume.]

I moreover wrote what may be the only actively anti-Keynesian introductory text, Free Market Economics: An Introduction for the General Reader, as the class text for my course, which I wrote over a twelve week period at the start of 2009 to explain in more detail what I was trying to say. The second edition published in 2014 is better (and co-published by the IEA in London) but conveys the same message.

An article by you would make a major difference to the willingness of others to take the problem with Keynesian economics seriously. The rest of this note is a template letter I have sent out to those who have already agreed to contribute.

\section{THE TEMPLATE LETTER}

The following is the template letter that was sent out to each of the contributors to this volume. 
The working title is: What's Wrong with Keynesian Economics? As I do not wish to pre-empt any approach that you might take, I will merely make a few observations and lay out a set of general guidelines that seem to me essential. There are also "further notes" that more or less repeat what is said in this letter but add further detail.

First, this is a book about economic theory. There is no need to demonstrate that the stimulus did not work. That is the premise and is beyond dispute. What is needed is an explanation of why it did not work. What is wrong with the Keynesian macroeconomics that was the basis for this undoubted policy failure? That is the central question I am asking you to answer.

Moreover, I don't think there is a great deal of value in going back to the General Theory to determine what "Keynesian" refers to. There is the "Keynesian economics" of 1936 and then there is the "Keynesian economics" of today. They are related but not the same. It is today's version we need to be responding to. Speaking for myself, the essence of "Keynesian" is the belief you can make an economy grow from the demand side, but I am very open to other ways of looking at even this threshold question. Some indication of what you believe makes a Keynesian model "Keynesian" might be useful, but again, let me emphasize, I am not intending to be prescriptive in any way.

Second, I will publish what you send. I will read through what I receive but only to ensure that the article has had at least a second set of eyes cast over it before publication. I will ask for clarification if I think it necessary but at no stage will I argue the economics with you although I can't promise I won't ask you to expand on some area. This is a forum for you to put your views across in a place that will be read. By being in the company of others who also think Keynesian economics is deeply flawed, your own contribution will be amplified by the company it keeps.

Third, the fundamental purpose of the book is to alert others that there are economists of standing who believe economic policy has been based on a false premise. Although we should attempt to have Keynesian economists re-think their allegiance to standard macro, they are not the intended core readership for this book. The aim is to encourage economists who are not committed to standard macro to recognize that there are other ways of looking at these issues, as well as to have policy makers and the public begin to question the standard Keynesian assumptions that have allowed the stimulus to occur without much appreciation of the risks that were being run.

Four, I would like each chapter to contain a bibliography of articles and books you believe are helpful in understanding what is wrong with Keynesian macro. These do not have to be cited in your article. The aim is to enable readers to deepen their own knowledge by being able to go to additional material that supports your perspective.

Five, the length of the article should be around 6000 words $+/-2000$. By all means longer if you think the extra length is required. The essence, however, is that the article be accessible but please say everything you believe needs to be said, remembering that these are only articles and not a book-length discussion. Lastly, if there is anyone you think ought to be invited to participate, please let me know. There seem to be only a very small number of economists that I can think of who have had a public position opposed to Keynesian economic theory and policy. There must be more. I just don't know who they are. Any suggestions would be greatly appreciated. 


\title{
ADDITIONAL CONSIDERATIONS
}

\author{
Below are the "additional considerations" that were sent out to each of the \\ authors which emphasized the points made above.
}

In the correspondence I have had in putting this book together I have had some extremely valuable feedback which has helped me refine what I am seeking to do and how to explain my intentions to others. These are further considerations about the article I am seeking. There is a logical order to these but there is also some repetition. I provide this only as an additional means to clarify the aim of the book and to assist you in framing your own article.

- This is to be a collection of newly written chapters on what is wrong with Keynesian economics.

- The emphasis is on what is wrong with Keynesian theory as a means to explain why Keynesian policies do not work.

- It is to be directed at an audience that will have previously studied economic theory, but will also partly be made up of an interested lay audience with no formal study in economic theory.

- The book is not, however, aimed at convincing committed Keynesians. It would, of course, be desirable if this could be done but that is very far from the primary focus.

- It is, instead, aimed at those who remain open to alternative views about the theoretical understanding that is required so that policies can be properly framed to restore more rapid growth and higher levels of employment.

- The book is premised on a recognition that the stimulus has been a failure. Increased public spending did not lead to recovery.

- The arguments ought to be the kind that would be read by a politician who is wondering why the stimulus has turned out to be such a failure or could be put before a first year economics class.

- You should feel free to use any argument you believe might be persuasive but my hope is that you will concentrate on the theoretical issues.

- Any statistics or maths used will need to have a great deal of explanatory power and ought to look as if they will be relevant a decade or more from now. But the decision is entirely yours.

- As to what constitutes a Keynesian approach, for the purposes of this volume it is the belief that following an increase in something called the level of aggregate demand, there will be an increase in economic activity, and as a result of the induced increase in economic activity, employment will rise along with living standards.

- Many who have been observing economic events must now be wondering why that has not happened. How would you explain to them: (1) what they have misunderstood and (2) how they should think about these issues instead?

- We each do part (2) whenever we explain to others why we prefer something else, and usually only in a piecemeal fashion. There seems to be little diagnosis about part (1), about where Keynesians go wrong.

- Here are some questions that come to mind in thinking about these issues but feel free to ignore these if they do not suit the direction you wish to travel: 
- What does it mean to be a Keynesian today, especially if you see it differently from being a framework based on raising aggregate demand?

- What do Keynesians believe is true that is not true?

- What are the flaws in their arguments?

- In looking at the world, what should they notice that would help them see why they have been misreading the way an economy works?

- How could they verify that there is a hole in their arguments?

- What could you point to that would help them see what is wrong with Keynesian theory.

- It need hardly be mentioned that this needs to be a polite discourse, however much exasperation we may feel.

- Nothing as direct and comprehensive has been done since Henry Hazlitt in 1959. Others who have attempted to do the same were Arthur Marget (2 volumes, 1938 and 1942), William Hutt (1963) and Mark Skousen (1992). But given the enormous extent of the Keynesian literature, this is a drop in the ocean.

- If you can think of anyone else who this request might go to, please also let me know. I cannot believe how few people there are who such a request might even go to.

- What I am seeking to do is to appeal to those who are not yet committed, and to those in policy-making roles to ensure that they understand that there is another point of view.

- Few will change their mind based on the work we have done specifically on Keynes. But our own previous work has brought us to the point where we can now write a simplified but compelling version of our beliefs in a way that will gain attention.

- We would be deceiving ourselves to believe that writing some book on economic theory dealing with Keynes's own writings and aimed at other economists would suffice as a means to change either modern theory or policy.

- If we are going to have an impact, we must assume that something called "Keynesian" economic theory is the intellectual support mechanism for "Keynesian" policy and that the events since 2009 have at least to some extent discredited that theory.

- We must explain that whatever it is about modern Keynesian macro that supports a stimulus is flawed. To go back to the General Theory and refute what Keynes wrote in 1936 is, in my view, futile.

- To attack the modern policy-focused version will at least give us an opportunity to shape our arguments in a way that others can learn from as to why the stimulus has been a failure.

- That is where we begin: everyone knows the stimulus has not worked. Everyone equally knows that macroeconomic theory says it should have worked. What, then, is wrong with the theory that has led to this disastrous policy outcome? That is the chapter I am looking for you to write.

- We are not arguing with Keynesians; we are arguing about why the policies did not work and the contribution that modern Keynesian macro has made to that failure. That is what I wish us to explain. 


\section{OUR PRESENT CIRCUMSTANCES}

Little has changed since the time of Hazlitt and Hutt. There are many economists, almost certainly the majority, who believe the stimulus following the GFC had a positive effect on economic activity and employment. Yet employment growth has been dismal, with even the minimal recoveries in activity so far experienced occurring only after the growth in public spending had been contained and in some cases even reversed. The problems of deficits and debt are everywhere to be seen. A return to rapid rates of output and employment growth remains distant and uncertain.

Our economies are being ruined by Keynesian macroeconomics. The chapters in this volume are designed to help you understand why that is. It is a scandal how little reflection and analysis there has been across the profession in the wake of the disastrous outcomes that have followed the stimulus. This volume is our attempt to redress at least some part of this grotesque imbalance.

While some kind of summary of the chapters might have been desirable, each is so unique that there really is no common theme other than an agreement that Keynesian economic theory needs to be replaced. While there are overlapping arguments between contributions, it would be the profoundest error even to attempt a summary of any of them. These are chapters which should be read on their own and in full. To provide a summary would be worse than futile; it would be certain to mislead you about the authors' intentions since they would have to be placed in a framework of my own.

Each chapter is self-contained. No summary of mine could do them justice. Each is argued from the premises each of the authors makes for themselves which can only be understood by reading the article in full. Not only do I feel myself incapable of summarizing what each author has said, it would also be a mistake even to try. If you have reached this far, you have shown at least that much interest in these issues. Reading the chapters for yourself is the only advice I can now give.

\section{A SUMMARY OF KEYNESIAN THEORY'S HISTORIC FAILURES}

What can be said is that the one thing all the authors do have in common is recognition that the application of Keynesian policies in a real-world environment does not provide answers to our economic problems. It is the very 
durability of Keynesian theory within modern macroeconomics that is perhaps its most remarkable achievement. The aim of each of the authors is to bring the demise of Keynesian economic theory that much closer.

The theory of aggregate demand entered our textbooks in the 1940s, where it has remained ever since. The occasions when one might have thought that Keynes had finally been discredited include all of the following, which is a summary of each of the major instances in which Keynesian economic policies had been applied and in which Keynesian theory had therefore failed.

- There is, first, the prolonged duration of the Great Depression in the United States following the introduction of high levels of public spending under the New Deal. Although much of it occurred before The General Theory was published, Roosevelt's increased levels of spending and deficit finance have often been highlighted as the prototype Keynesian policy. The failure of the New Deal, especially when contrasted with the almost instantaneous success of the diametrically opposite policies pursued by Harding at the commencement of an inflationary recession in the early 1920s, should have provided a warning to others. It did not.

- The post-war recovery after 1945 , arguably the most robust and sustained period of economic growth in history, followed the immense cuts to public spending and the balancing of the budget in the United States which occurred from the moment the war had ended. Millions of soldiers were returning from overseas and needed to find peacetime jobs. Wartime industries were closing down. Public spending fell like a rock. Yet, in spite of the downturn in wartime industries, the huge increases in the number of persons looking for jobs and the massive cuts to public spending, the American economy boomed. There were, as one might have expected, many warnings by Keynesians that the American economy would immediately return to recessionary conditions if some kind of deficit-financed stimulus were not introduced. Again the failure to predict ought to have been a warning, but again it was not.

- The Great Inflation of the 1970s and 1980s was brought on by immense increases in deficit spending starting from the end of the 1960s which remained until the 1990s. The combination of recession and inflation was itself said to contradict Keynesian theory. But while the theory was shown to provide no guidance to policy, aggregate demand remained embedded within textbook theory, although now supplemented by aggregate supply. Whatever lessons might have been learned were ignored. 
- The Japanese economic stimulus of the 1990s ought itself be a reminder of the potential for harm that Keynesian policies bring. In many ways, the Japanese economy had been the single greatest post-war success story. By the late 1980s, Japan's was the most robust economy in the world. The downturn experienced by the Japanese at the end of the decade was experienced across the globe. What was different was the deficit-financed public spending stimulus that was introduced during the early 1990s to generate recovery. And while there are many different explanations that have been offered over the years for the subsequent failure of the Japanese economy to return to full employment and robust rates of growth, the absence of a post-mortem in which the stimulus was closely investigated indicates the extent to which the application of Keynesian theory has moved to become a position of unquestionable authority. Even where Keynesian policy could be seen not to have succeeded, other explanations for that failure were central to every such analysis, not the expenditure policy itself.

- The confidence with which stimulus packages were applied across the world over the period 2009-11 to reverse the effects of the Global Financial Crisis indicates that whatever past failures may have been associated with Keynesian policies, these associations were extremely weak in the minds of those who set out to restore growth and full employment by deficit-financed increases in public spending. The lack of recriminations and the policy soul-searchingthough no recovery has occurred and, indeed, even though economic problems have deepened - indicates the extent to which Keynesian macro remains more entrenched than ever. An abject failure though the policy has been, to the extent that recovery remains the actual measure of success, the absence of any public recognition among mainstream economists that standard macroeconomic theory has shown itself to be a disastrous guide to policy may be the most astonishing aspect of the entire sequence of economic events since the start of the GFC.

What unifies the writers in this collection is their recognition that Keynesian economic theory provides no useful guidance in dealing with our economic problems. The book brings together the views of economists from a number of different schools of thought. Their aim is to have you share their understanding of what is wrong with Keynesian economic theory and the policies this theory promotes. 


\section{REFERENCES}

Hazlitt, Henry (1959), The Failure of the "New Economics": An Analysis of the Keynesian Fallacies, New Rochelle, NY: Arlington House.

Hutt, W.H. (1963), Keynesianism - Retrospect and Prospect: A Critical Restatement of Basic Economic Principles, Chicago: Henry Regnery Company.

Kates, Steven (2009), "The dangerous return of Keynesian economics", Quadrant, LIII (3), March.

Kates, Steven (2014a), Free Market Economics: An Introduction for the General Reader, 2nd edn, Cheltenham, UK and Northampton, MA, USA: Edward Elgar Publishing.

Kates, Steven (2014b), “Keynesian economics' dangerous return - five years on”, Quadrant, LVIII, March.

Marget, Arthur W. ([1938] 1966a), The Theory of Prices: A Re-Examination of the Central Problems of Monetary Theory, Vol. I, New York: Augustus M. Kelley.

Marget, Arthur W. ([1942] 1966b), The Theory of Prices: A Re-Examination of the Central Problems of Monetary Theory, Vol. II, New York: Augustus M. Kelley.

Skousen, Mark (ed.) (1992), Dissent on Keynes: A Critical Appraisal of Keynesian Economics, New York: Praeger. 